\title{
Usefulness of Accounting Information System in Emerging Economy: Empirical Evidence of Iran
}

\author{
Mahdi Salehi (Corresponding author) \\ Assistant Prof. Accounting and Management Department, Zanjan University, Iran \\ Tel: 98-912-142-5323Ｅ-mail: Salehimahdi_ir@yahoo.com \\ Vahab Rostami \\ Faculty Member of Pyame Noor University, Zanjan Branch, Iran \\ Abdolkarim Mogadam \\ Faculty member of Pyame Noor University, Gharmsar Branch \\ Accountancy at Allamehtababtabi University, Tehran, Iran
}

\begin{abstract}
The main objective of an accounting information system (AIS), a pre-eminently user-oriented system, is the collection and recording of data and information regarding events that have an economic impact upon organizations and the maintenance, processing and communication of information to internal and external stakeholders. The results of this study show that although AIS is very useful to Iranian corporation, it is a gap between what AIS is and what should be.
\end{abstract}

Keywords: Information system, Accounting Information System, Iran

\section{Introduction}

AIS of the past focused on the recording, summarizing and validating of data about business financial transactions. Accounting systems that were previously performed manually can now be performed with the help of computers. Therefore, improvements in the information technology have facilitated the use of cost and management accounting procedures. Developments in IT have been paramount in recent decades, and they have been leading developments in the globalization of markets and societies (Castells, 1996). In the view of the fact, it is widely acknowledged that IT plays an important role in the field of accounting; IT can be strategic weapons to support the object and strategy organizations. Some business organizations get competitive advantage by equipping new information systems. Therefore organizations tend to increase the money for IT, which makes the ratio of IT investment to their total budget higher.

In an era of global competition, the key to a firm's survival is the continuous improvement of its performances.

AIS of the past focused on the recording, summarizing and validating of data about business financial transactions. These functions were performed for the various groups within the organization that were concerned about the respective decisions associated with financial accounting, managerial accounting, and tax compliance issues (Hollander et al. 1996).

The need to integrate these often diverse systems led to the accountant's appreciation of shared databases that provide a cohesive picture of the organization's data, eliminating duplications and reducing data conflicts (Moscoveet al. 1999).

The bold claims that technology has had the most important impact as accounting has been transformed into a knowledge services profession have in general been poorly reflected in recent accounting research. Furthermore, the research tradition in the AIS field, concentrating on, for example, transaction processing, data structure modeling, computer fraud and security as well as system development methodologies, seems not to have produced a useful understanding of the interplay between modern IT and accounting/management control (Granlund \& Mouritsen, 2003). According to Flynn (1992), the effectiveness of accounting information systems can be received providing management information to assist concerned decisions. By Corner (1989) the effectiveness of AIS can be evaluated as added value of benefits. Gelinas (1990) considers the effectiveness of AIS as a measure of success to meet the established goals. The success of AIS implementation can be defined as profitably applied to area of major concern to the organization, is widely used by one or more satisfied users, and improves the quality of their performance. According to the above benefits which drives from AIS to corporate 
sector, in this paper the authors try to illustrate this importance as well in developing country namely, Iran. Here before explaining AIS, the authors briefly going to explain on information system.

\section{Information Systems}

An information system is an organized means of collecting, entering, and processing data and storing, managing, controlling, and reporting information so that an organization can achieve its objectives and goals (Romney et al., 1997:18). This definition of information system shows that an information system has following components.

Every information system is designed to accomplish one or more goals or objectives. For example, an information system may be designed to collect and process data about employees to help managers prepare payroll reports.

Inputs: Data must be entered into the information system to be processed.

Data are the facts that are collected and processed by the information system. Data are meaningless and useless, which, therefore, should be processed and transformed to meaningful, organized, and useful form that is called information.

Outputs: Output is the meaningful and useful information produced by the information system. For example, weekly payroll report produced by the information system is an output.

Data storage: In addition to the external data entered into the information system, there should be internally stored data used for processing.

Processors: In order to produce useful and meaningful information, data must be processed. Most companies process data by using computers.

Instructions and Procedures: An information system produces data by the following instructions and procedures. In computerized information systems, software includes procedures and instructions that direct computers to process the data.

Users: Users are people who use the information produced by the system and who interacts with the system. For example, managers who use financial statements that are produced by an accounting information system are the users of the information system.

Control Measures: In order to make the information system produce correct, and error free information, necessary measures should be taken to protect and control the information system.

Any system that includes the above components is known as an information system. The following section will show how accounting systems are established using these components.

\section{AIS}

Accounting is the service function that seeks to provide the users with quantitative information. On the other hand, AIS is an information system that is designed to make the accomplishment of accounting function possible. AIS processes data and transactions to provide users with the information they need to plan, control, and operate their businesses (Romney et al., 1997:2).

AIS can be a manual system, or a computerized system using computers. Regardless of the type, AIS is designed to collect, enter, process, store, and report data and information.

\section{Importance of AIS}

Generally, information system is the whole of the related components that are working together to collect, store and disseminate data for the purpose of planning, control, coordination, analysis and decision making.

On the other hand, an AIS is the whole of the related components that are put together to collect information, raw data or ordinary data and transform them into financial data for the purpose of reporting them to decision makers.

The most important and oldest of the present systems in businesses is certainly the Management Information System. "Management" and "information" are two inseparable concepts and show the impossibility of the rational execution of management activities without information. Management Information System consists of many subsystems. Accounting Information System is one of these subsystems and the oldest one.

The accounting information system that is created in a business is directly related to the organizational culture, level of strategic planning and the information technologies that this specific business has. It is possible to obtain healthier information about the financial structures of the businesses that have set up a good accounting information system. Some of the important functions that an accounting information system perform in a 
business are: collecting and recording data about the activities and transactions; planning; processing the data and turning it into information to be used in decision-making for planning, application and control activities; and carrying out the necessary controls in order to protect the business assets.

Accounting information plays an important role in the process of managing an enterprise's activity. In the last ten years, there has been an intensive process of implementing AIS in the world. These systems were implemented in large industrial and small trade enterprises. Later, implementation of AIS started in other enterprises and state institutions. The implementation of AIS is quite an expensive investment project for most enterprises. However, in practice, the decision on which AIS to actually implement is, in most cases, based on advertisement or the suggestions of associates. Flynn (1992) has found that only $20 \%$ information systems were used successfully, while other installation effect was neutral or negative. These arguments show an importance for evaluating the AIS effectiveness.

According to Flynn (1992), the effectiveness of AIS can be received providing management information to assist concerned decisions with regard to the successfully managing of corporations. By Corner (1989) the effectiveness of AIS can be evaluated as added value of benefits. Gelinas (1990) considers the effectiveness of AIS as a measure of success to meet the established goals. The success of AIS implementation can be defined as profitably applied to area of major concern to the organization, is widely used by one or more satisfied users, and improves the quality of their performance. On the basis of made research authors come to conclusion, AIS effectiveness can be considered as successful use of system, which ensures user's needs.

The effectiveness of AIS can be evaluated using one or several models. Usage of several models increase reliability of evaluation.

\section{Features of AIS}

Information system is perceived as an entirety of information processing system and resources of an enterprise meant to form and disseminate information. Lucey (1991) has established that the system of information is a set of unanimously operating people, data and procedures for the purpose of providing useful information. Contemporary IS cannot function without computers and other technical means to measure primary information, gather and register it in carriers, process and transmit it to consumers. For this reason computerized information systems (CIS) are designed and implemented.

Some other researchers (Domeika, 2005) consider software an important element of computerized IS with which technical equipment is able to arrange information in an automated way, create accounting CDB and is available to users according to their needs. CIS of an enterprise accounting help to automate the processes of enterprise performance accounting and arrangement of analytical information. Accounting, being a special information system, should reveal the real picture of enterprise capital increase, sources of income and added value formation, approaches for revenue and profit distribution, scope of consumption and storage.

Under the development of market economics the requirements for accounting information are changing and there should be a significant step towards the improvement of methodology of its preparation, processing and issue to users. When Lithuanian accounting is integrating into the system of European accounting it is not sufficient to have good law regulating accounting, forms of financial reports, plan of accounts, standards of business accounting. Other elements are also important for the system of accounting including profession of accounting and code of its ethics, training and retraining of specialists of accounting, scientific research of accounting, etc. (Mackevicius, 2007, Bruzauskas et al, 2005). The quality of accounting information is also determined by other factors such as the level of primary information automation, functionality of computer software, integration of accounting and other types of economic information, etc. Accounting information is closely related to other types of economic information such as normative and target information and, especially, analytical information (or results of analysis). Accounting in its broad sense includes not only accounting itself but also the analysis of economic performance, management control and internal audit.

For a long time the analysis of an enterprise economic performance in western countries used to be restricted to the analysis of the financial state, that is, the research of an enterprise cost-effectiveness, solvency. In the $2^{\text {nd }}$ part of the $20^{\text {th }}$ century a contemporary system of accounting evolved whose core elements were as follows: financial accounting and accountability, management accounting and control, financial analysis on the basis of financial accountability. Economic analysis should definitely not limit itself to the analysis of financial performance merely; rather, it should encompass all conjunctions of economic performance. The object of economic analysis is economic performance of enterprises. Economic analysis occupies the intermediate position between the selection of information and processing functions and the functions of decision making. Creating and implementing the accounting IS the objectives of economic analysis and their solutions should become an 
inseparable part of AIS. In sum, it arises to help managers at every position, according to Mitchell et al. (2000) argued that accounting information could help manage short-term problems in areas such as costing, expenditure and cash flow by providing information to support monitoring and control.

However, the existing literature provides little evidence of AIS development within corporations. Many studies suggest that corporations have little management information and poor control, and that decision-making is mostly ad hoc (Marriot \& Marriot 2000). McMahon (2001), for example, suggested that financial accounting has remained the principle source of information for internal management in corporations. Marriot \& Marriot (2000) also suggested that financial awareness among managers of corporations varies considerably and that the use of computers for the preparation of management accounting information is not at its full potential.

\section{Advantages of AIS}

According to the several researchers, AIS have a lot of benefits to any company and corporation as follow:

\section{Good cooperation}

Any thing is always linked to certain environment, exists and develops third-party logistics enterprises in the supply chain linking play a role of a bridge. Although the third-party logistics business as a separate entity exist in the market, it and other enterprises still have to maintain a close relationship. This is because the consumers in order to ensure normal operation of their production, they must understand and control the flow and the keeping of materials timely, which calls that third-party logistics enterprises accounting information systems cooperate with up-downstream enterprises, together control and manage the value-added activities occurred in the whole supply chain, and achieve really supply chain competition. In addition, in the traditional enterprise organization mode, the enterprise's business activities are divided in accordance with the functions and implement, so the lack of co-ordination between departments the "islands of information" inevitably come into being. The new system really record and reflect the economic business activities, do not require accountants note into the system according to the pre-format, consequently avoid duplication of information collection and shortcomings; and accountant no longer were limited to the accounting departments, but to participate in the enterprises operational activities to coordinate other departments do well accounting information records and analytical work. In addition, other companies could line on a third party logistics enterprises accounting information system through the Internet, timely query and know the flow situation of logistics, do well their production plans.

\section{To meet the needs of multi-users}

With the change of the environment, the use objects of accounting information become expansion, including all levels of enterprise management, all investment bodies outside, government agencies, intermediary organizations, and so on, among them there are accountant and non-accountant. Traditional accounting information system can only generate financial statements afforded to financial executive and fewer accounting information, which make the use objects become narrow. But in the new system entity DB record all resources and economic business activities, users through event-driven buttons on interactive interface can get the information they want. According to the value chain management, any of the activities should be the value-added process, and account is a measure means of the value of economic activity, therefore, any economic activity through the accounting information system can be measured and reflected. However, as part of the current business activities can not be measured by money, and we are currently unable to find suitable means of measuring the value, which caused some economic activities not reflected through accounting information system.

\section{To control afterwards, and control in advance and in concurrent}

Account has the functions of supervision and control of the economic activities of the enterprise. And the traditional manual account and of the computer accounting system for "accounting" can only do inspection afterwards, the mistakes could not be avoided. New accounting information system integrate of real-time processing, the standard cost, authorized the approval process control, budget management, and so on, so that employees based on the standard budget, change from passive to active to manage their own activities, do Real-time check, control, and timely identify problems, correct deviations and do truly Control afterwards, in advance and in concurrent.

Brynjolfsson and Hitt (2003) estimated a production function for a panel of 600 large US firms, finding that the contribution of IT investments to output growth significantly exceeds its factor share, implying a positive effect of computers on productivity growth in the long-run. The results also suggest that IT capital deepening is associated with far-reaching organizational changes within the firm.

OECD (2004) gathers a set of empirical papers that offers a comprehensive overview of the impacts of IT on economic performance in advanced countries. The nine studies based on micro-data show significant impacts of 
digital technologies on firm-level performance. In most cases there is also evidence that IT investment is associated with more rapid TFP growth and that this effect differs across industries. Firms in the financial sector are among those that have benefited more from the new technologies.

\section{Research Problem}

The developments in information technologies, together with globalization and international legal arrangements, have generated such notions as "new economy", "e-commerce" and "new accounting". In addition, these developments have been useful in saving time and money and reducing the costs by accelerating transactions and communication. The developments in information technologies have caused all or some of the financial transactions in a business to be carried out in such different forms in electronic environments as electronic commerce and electronic data exchange. This, as a result, caused the financial transactions to be removed from the traditional paper-based activity environment to the electronic environment in the accounting information system, which is described as the language of a business, and therefore, resulted in changes in all processes such as recording, classification, reporting and analysis. At the same time, this change has also affected such accounting applications as keeping the books, preparing financial statements and tax statements, auditing activities and, therefore, the activities of the members of the accounting profession.

The above-mentioned developments in information technologies, which made the changes in accounting information system, applications and profession inevitable, also created a change in the demands of the society and an increase in the expectations from the members of accounting profession. So, in this paper the authors try to shows the significance of accounting information system in developing country, namely Iran.

\section{Related literature}

Computers are now a key resource in accounting and financial information processing. Furthermore, major advances in information technology (Seligman, 2000) as well as the existence of observable and tangible economic benefits (Botosan, 1997 and Seligman, 2000) have driven traditional auditing and financial reporting ever closer to being real-time tasks. Companies like Cisco Systems have made significant progress in making real-time financial reporting a reality (Seligman, 2000). Seligman (2000, p.148) reports that "Cisco Systems is one of the rare companies today in which the boss can clap his hands and get the books closed within an hour."

\section{Real-time financial reporting}

Although real-time financial reporting provides benefits to investors and financial analysts, prior discussion regarding the use of technologies that would bring the business community closer to real-time financial reporting has raised several concerns. For instance, when Cushing (1989) wrote about the emergence of the Securities and Exchange Commission's EDGAR (Electronic Data Gathering, Analysis, and Retrieval) system (SEC, 2000 a), he examined the feasibility and consequences of using a database approach to corporate financial reporting. The database approach is a precursor to the current Internet client/server based portal approach. At the time of Cushing's work, the World Wide Web did not exist, and Bernard-Lee's HTML (W3, 2000) was not yet invented. Nonetheless, the issues addressed by Cushing are still relevant and point to a need for reexamination of the content of accounting information systems education. In his work, Cushing found that the database approach would be feasible for financial reporting. Yet, he also recognized that this approach would have varying economic effects on several players in the economy. One of his observations dealt with which players might support the database approach and which ones might oppose it. Cushing (1989) conjectured that the most likely supporters of the database approach would be governmental agencies involved in regulatory enforcement, accounting scholars, and the data processing industry. On the other hand, the most likely opponents might be corporate management, corporate accountants, financial analysts, and investors with private access to inside information. Cushing (1989) argued that corporate management might object to the database approach because it would hinder their ability to manipulate financial information in a manner that best serves their self-interest. Cushing believed that the database approach would enable meticulous monitoring and appraisal of management's accounting choices. As a result, he reasoned that this approach would almost certainly lead to restrictions in these choices, and that corporate management might experience a significant reduction in their ability to manage earnings. Similar arguments could be made about real-time financial reporting in the context of today's environment as it could lead to greater transparency in financial reporting and enable more efficient monitoring of management's accounting method choices. Since 1989, technological advancements and the World Wide Web have transformed the way users of financial reports seek financial information and how corporations have supported (albeit selectively), through their web pages, users' demand for timely information. The emergence of the World Wide Web has also made the "nearly real-time" financial reporting convenient and economical for individual investors. Constantly updated World Wide Web pages have shown investors that they 
may have the opportunity to acquire financial information on a real-time basis. It might be argued that the cost of disclosing information real-time and/or the fear of passing on proprietary information to competitors might discourage companies from disclosing their financial information in a real-time manner. However, these disadvantages might be offset by the impact of timely disclosures on the cost of capital. Botosan (1997) found that the cost of capital is lower for companies (particularly smaller entities) that provide more thorough and timely financial disclosure than those companies that do not. Botosan's findings provide some insight into the potential benefits that might accrue from real-time financial reporting.

\section{Assurance services for real-time reporting}

The quality and effectiveness of real-time financial reporting is contingent upon the ability to provide real-time, continuous financial auditing. Continuous auditing has been defined as "a methodology that enables independent auditors to provide written assurance on a subject matter using a series of auditors' reports issued simultaneously with, or a short period of time after, the occurrence of events underlying the subject matter" (CICA/AICPA, 1999). Continuous auditing requires a high degree of automation. It is also dependent upon (a) precise definitions of the data underlying the items to be audited, (b) use of real-time controls to signal errors and irregularities, and (c) automated integrated audit agents and other technologies that enable collection, analysis, summarization, and reporting of audit evidence and opinions. Like real-time financial reporting, real-time, continuous auditing also creates a need for a new breed of accounting information systems professionals, who are not only well-versed in traditional audit and accounting methods, but also information technology (IT).

\section{Changing nature of financial information systems and enabling technologies}

The possibility of sharing very timely financial data and information on the Web has accelerated many new developments in financial reporting that have the active support of the corporate community. One such significant breakthrough is XBRL (Extensible Business Reporting Language, 2000), a variation of XML (Extensible Markup Language), for financial reporting. XBRL is expected to make it easier to locate, retrieve, and use financial data that are published on the Web. Moreover, by establishing penalties for private, preemptive disclosure of financial information to exclusive groups such as financial analysts, the recent SEC fair disclosure ruling provides additional impetus for advances in real-time reporting to the entire business and investing community (Seligman, 2000). Corporations may now attempt to make timely (including real-time) information available to all market participants rather than select groups of analysts and investment bankers. In order to reach a distributed audience, real-time financial reporting and auditing require sophisticated network technology and Web-based systems. As advances in real-time financial reporting and auditing continue, a new breed of accounting practitioners and accounting scholars may question and subsequently reexamine some of the fundamental assumptions made under the guise of manual systems usage during most of the last century. As demonstrated by EDGAR (SEC, 2000 a) and other media available via the World Wide Web, the fundamental assumptions underlying modern accounting may need to be thoroughly reexamined in this post-modern age in which the media for financial communication is no longer confined to a linear time frame, but rather is capable of accommodating spatial data points within dynamic financial transactions.

\section{Hypotheses development}

According to Huber (1990, p.65), “... use of advanced IT leads to more available and more quickly retrieved information, including external information, internal information, and previously encountered information, and thus leads to increased information accessibility". Firms with extensive resources may gain a competitive edge by deploying IT in support of or to strengthen their business (King et al. 1989). Chan et al. (1997) and Hussin et al. (2002) found that an appropriate level of IT sophistication was associated with the capability to align IT strategy and business strategy. Hence, it is expected in well developed country used higher level IT and visa versa.

According to the benefits and advantages of IT and research problem the below hypotheses is postulated to give clear answer to the researchers:

First hypothesis: utilizing of accounting information counseling cause to increases accounting and financial performance.

Second hypothesis: Accounting information system cause subtle predict of company future.

Third hypothesis: Accounting information system cause to more correctness of financial reporting.

Forth hypothesis: Accounting information software improves accounting standards in Iran.

Fifth hypothesis: Accounting information software confirms with other financial and managerial systems. 
Sixth hypothesis: Accounting information system covers all information needs of company.

Seventh hypothesis: Accounting information system covers all management levels information in Iran.

\section{Research methodology}

So far accurate answer to the research question, the authors design and developed a questionnaire which it is the most suitable for this study. A survey questionnaire was completed by the financial managers of Iranian corporations. The questionnaire contains two parts namely (A) bio-data and (B) this section includes several deep questions related to AIS application and usefulness in Iranian corporations. The questionnaire was based on Five-Point Likert,s Scale questionnaire. The Five-Point Likert's scale having the ratings of "strongly disagree" (1) and "strongly agree" (5) were used. Totally 600 questionnaire were distributed among the financial managers in Iran. Out of 600 questionnaires, 498 useable questionnaires were returned in first Feb to end of April 2009.

Table 1 shows more details of participants regarding gender, academic degree, experience, and background of study of 498 participants. According to Table 1, $75.50 \%$ of participants were male and $24.10 \%$ were female. In sum, majority of participants were male. Majority of participants had bachelor degree (240 numbers, 48.20\%), followed by $46.78 \%$ master degrees. Minority of participants had diploma degree $(2.61 \%)$. The least number of participants had $\mathrm{PhD}$ degrees (2.41\%). To conclude, majority of Iranian financial managers in this study had bachelor degrees.

Regarding to experience, 258 participants had more than 10 years experience, followed by $23.70 \%$ more than 15 years experience. Least number of participants had lee than 4 years experience $(0.80 \%)$.

Regarding to the academicals background, $67.27 \%$ had accountancy background. More than $25 \%$ of participants had management background.

Insert Table 1 Here

\section{Testing of hypotheses}

For the purposes of testing hypotheses the suitable test was adapted in this study. Chi Square Test was employed in this study and the results of hypotheses are shown in Table 2.

First hypothesis: utilizing of accounting information counseling cause to increases accounting and financial performance.

According to Table 2 the mean value, S.D, and D.f are 3.965, 1.434, and 2 respectively. The results of above mentioned table shows that the first hypothesis is accepted. It means the utilizing of accounting information counseling cause to increase accounting and financial performance. Hence null hypothesis is rejected. To conclude, for improving accounting and financial performance sophisticate AIS should be adapt in Iranian corporations.

Second hypothesis: Accounting information system cause subtle predict of company future.

With reference to Table 2, this hypothesis also accepted and null hypothesis rejected. In other words, implementation of high AIS leads to better future prediction of corporations in Iran.

Insert Table 2 Here

Third hypothesis: Accounting information system cause to more correctness of financial reporting.

Table 2 shows that this hypothesis also strongly accepted in Iranian corporate sector. It means, any company which adapted high AIS it has more correct financial statements as well as reliable financial reporting.

Forth hypothesis: Accounting information software improves accounting standards in Iran.

With regard to Table 2 this hypothesis rejected and null hypothesis accepted, in other words, accounting information software does not harmonize with Iranian accounting standards.

Fifth hypothesis: Accounting information software confirms with other financial and managerial systems.

According to Table 2 this hypothesis also rejected and null hypothesis accepted, in other words Iranian AIS does not confirms with other financial and managerial systems, so there is a gap between AIS and financial and managerial systems. In reality it causes very weakness to Iranian corporations because if all systems fit each others then company will take off to any target.

Sixth hypothesis: Accounting information system covers all information needs of company.

As Table 2 shows the sixth hypothesis also rejected and null hypothesis accepted, in other words, Iranian AIS does not provide suitable information to company, so those companies can not make decision with reliable data. 
According to the authors view points, the major weakness of Iranian corporations is that they are implementing AIS but it is not very useful to corporations, so there is also gap so called AIS gap.

Seventh hypothesis: Accounting information system covers all management levels information in Iran.

The seventh hypothesis also rejected by Table 2. It means that AIS in Iran does not covers and provide management levels information. It is another weakness of Iranian corporations which available AIS do not provide managements' information needs.

\section{Conclusion}

Accounting information systems of the past focused on the recording, summarizing and validating of data about business financial transactions. These functions were performed for the various groups within the organization that were concerned about the respective decisions associated with financial accounting, managerial accounting, and tax compliance issues (Hollanderet al.1996). The need to integrate these often diverse systems led to the accountant's appreciation of shared databases that provide a cohesive picture of the organization's data, eliminating duplications and reducing data conflicts (Moscove, et al. 1999). The results of this study showed that AIS improve financial statements and reporting correctness in Iran. However, the results also revealed that there is hug gap between what AIS and what should be. The major weakness of AIS in Iran as follow: in is not affected to Iranian accounting standards, it is not confirms with other financial and managerial systems, it is not covers all information needs have company and financial information and it is not covers all management levels information in Iran. So, to this situation, the managers which are aware of AIS benefits should take more as well as academicals action for reducing such gaps in Iranian corporate sectors.

\section{References}

Botosan, Christine A. (1997). Disclosure Level and the Cost of Equity Capital, The Accounting Review, Vol. 72 (July), pp. 323-349.

Bresnaham T., E. Brynjolfsson, L. Hitt (2002). Information Technology, Workplace Organization and the Demand for Skilled Labor: Firm Level Evidence, Quarterly Journal of Economics, 17: 339-376.

Bresnahan et al. (2002). find a positive correlation between the accumulation of IT capital, innovation in workplace organization and the use of more highly skilled workers.

Brynjolfsson E. L.M. Hitt (2003). Computing Productivity: Firm-Level Evidence, Review of Economics and Statistics, Vol. 85, pp. 793-808.

Castells, M. (1996). The Information Age: Economy, Society and Culture. Volume I, The Rise of the Network Society. Oxford: Blackwell.

Chan, Y.E., S.L Huff, D.W. Barclay, and D.G. Copeland (1997). Business strategic orientation, information systems strategic orientation, and strategic alignment, Information Systems Research, vol. 8, no. 2, pp. 125-150.

CICA/AICPA, (1999). Continuous Auditing, Canadian Institute of Chartered accountants, Toronto, Canada.

Cobb, I. (1993). JIT and the Management Accountant: A Study of Current UK Practice, CIMA, London.

Corner R. (1989). Systems Analysis for Profitable Business Applications, Prentice Hall.

Cushing, B. E. (1989). On the Feasibility and the Consequences of a Database Approach to Corporate Financial Reporting, Journal of Information Systems, spring, pp. 29-52.

Extensible Business Reporting Language, Available online: http://www.xfrml.org/.

Fisher, J. (1992). Use of nonfinancial performance measures, Journal of Cost Management for the Manufacturing Industry, Spring, pp. 31-8.

Flynn D. (1992). Information systems Requirements: Determination and Analysis. MCGRAW - HILL Book Company.

Foster, G. and C.T. Horngren, (1987). JIT: cost accounting and cost management issues, Management Accounting (USA), Vol. 68 No. 12, pp. 19-25.

Gelinas U., A. Oram, W. Wriggins (1990). Accounting information systems, Pwskent Publishing Company: Boston.

Granlund, M., and J. Mouritsen, (2003). Problematizing the relationship between management control and information technology, Introduction to the Special section on 'Management control and new information technologies', European Accounting Review, Vol. 12, No. 1, pp. 77-83. 
Green, F.B., F. Amenkhienan, and G. Johnson, (1991). Performance measures and JIT, Management Accounting (USA), Vol. 72 No. 8, pp. 50-3.

Hollander, A., E, Denna and J.Cherrington (1996). Accounting, Information Technology, and Business Solutions, Chicago, IL: Richard D. Irwin.

Hollander, A., E. Denna, and J. Cherrington, (1996). Accounting, Information Technology, and Business Solutions. Chicago, IL: Richard D. Irwin.

Huber, G.P. (1990). A theory of the effects of advanced information technologies on organizational design, intelligence, and decision making, Academy of Management Review, vol. 15, no. 1, pp. 47-71.

Hussin, H., M. King, and P.B. Cragg. (2002). IT alignment in small firms, European Journal of Information Systems, vol. 11, pp. 108-127.

King, W.R., V. Grover, and E. Hufnagel. (1989). Using information and information technology for sustainable competitive advantage: some empirical evidence, Information and Management, vol. 17, pp. 87-93.

Lucey, T. (1991). Management Information Systems, London: DP Publications Limited, 326 p. Domeika, P. Secondary Economic Information of an Enterprise and its Computerized Arrangement//Engineering Economics, ISSN 1392-2785. Kaunas: Technologija, 2005, No. 5(45), p. 12-18.

Mackevičius, J. Imonių veiklos analiz (2007). Informacijos rinkimas, sisteminimas ir vertinimas. Monografija. Antrasis pataisytas ir papildytas leidimas. Vilnius: TEV, pp. 306-320.

Marriot, N. and P. Marriot (2000). Professional accountants and the development of a management accounting service for the small firm: Barriers and possibilities, Management Accounting Research, vol. 11, pp. 475-492.

McIlhattan, R.D. (1987). How cost management systems can support the JIT philosophy, Management Accounting (USA), Vol. 69 No. 3, pp. 20-6.

McMahon, R.G.P. (2001). Business growth and performance and financial reporting practices of Australian manufacturing SMEs', Journal of Small Business Management, vol. 39, no. 2, pp. 152-164.

Mitchell, F., G. Reid, and J. Smith, (2000). Information system development in the small firm: The use of management accounting, CIMA Publishing, United Kingdom.

Moscove, S., M. Simkin and N. Bagranoff (1999). Core Concepts of Accounting Information Systems, New York, NY: John Wiley \& Sons, Inc.

Moscove, S., M. Simkin, and N. Bagranoff (1999). Core Concepts of Accounting Information Systems, New York, NY: John Wiley \& Sons, Inc.

Romney, Marshall B., Steinbart, Paul John, Cushing, E. Barry (1997). Accounting Information System, Seventh Edition, Addison-Wesley.

Securities and Exchange Commission, EDGAR Database of Corporate Information, Available online: http://www.sec.gov/edgarhp.htm.

Securities and Exchange Commission, Selective Disclosure and Insider Trading, August 15, 2000, Effective date: October 23, 2000. [Release Nos. 33-7881; 34-43154; IC-24599, File No. S7-31-99](File name: 33-7881.htm) Available online: http://www.sec.gov/rules/final/33-7881.htm.

W3, Some early ideas for HTML, Available online: http://www.w3.org/MarkUp/\#historical. 
Table 1. General information of participants

\begin{tabular}{|c|c|c|c|}
\hline \multirow{2}{*}{ Gender } & Mariable & Number & Percent \\
\cline { 2 - 4 } & Female & 378 & 75.90 \\
\hline \multirow{3}{*}{$\begin{array}{c}\text { Academic } \\
\text { degree }\end{array}$} & Diploma & 120 & 24.10 \\
\cline { 2 - 4 } & B.S & 13 & 2.61 \\
\cline { 2 - 4 } & M.A & 240 & 48.20 \\
\hline \multirow{3}{*}{\begin{tabular}{c} 
Experience \\
\cline { 2 - 4 }
\end{tabular}} & PhD & 12 & 46.78 \\
\cline { 2 - 4 } & Less than 4 & 4 & 2.41 \\
\cline { 2 - 4 } & 5-9 & 118 & 0.80 \\
\hline \multirow{3}{*}{$\begin{array}{c}\text { Background of } \\
\text { the study }\end{array}$} & More than 15 & 118 & 23.69 \\
\cline { 2 - 4 } & Bccountancy & 335 & 51.81 \\
\cline { 2 - 4 } & Fininess management & 128 & 23.70 \\
\cline { 2 - 4 } & Other & 22 & 25.70 \\
\hline
\end{tabular}

Table 2. Results of testing hypotheses

\begin{tabular}{|c|c|c|c|c|c|c|}
\hline Hypotheses & Mean & S.D & d.f & $\begin{array}{c}\text { Chi } \\
\text { Square }\end{array}$ & Asymp. Sig & Results \\
\hline First hypothesis & 3.965 & 1.434 & 2 & 8.600 & 0.014 & Accepted \\
\hline Second hypothesis & 2.123 & 0.527 & 3 & 13.868 & 0.003 & Accepted \\
\hline Third hypothesis & 2.297 & 0.786 & 3 & 10.140 & 0.017 & Accepted \\
\hline Fourth hypothesis & 2.485 & 0.649 & 1 & 4.118 & 0.981 & Rejected \\
\hline Fifth hypothesis & 2.316 & 0.635 & 3 & 3.972 & 0.624 & Rejected \\
\hline Sixth hypothesis & 2.461 & 0.792 & 2 & 0.160 & 0.923 & Rejected \\
\hline Seventh hypothesis & 2.438 & 0.758 & 2 & 1.920 & 0.383 & Rejected \\
\hline
\end{tabular}

